\title{
Analyses of the anthropometric data from the North/South Ireland Food Consumption Survey
}

\author{
SN McCarthy ${ }^{1,2, *}$, KE Harrington ${ }^{1}$, M Kiely $^{3}$, A Flynn $^{3}$, PJ Robson ${ }^{4}$, MBE Livingstone ${ }^{4}$ and \\ MJ Gibney' \\ Irish Universities Nutrition Alliance (IUNA) at: 'Department of Clinical Medicine, Trinity Centre for Health Sciences, \\ St James's Hospital, Dublin 8, Ireland: ${ }^{2}$ Present address: IUNA, Room 2.7 (2nd Floor), Biotechnology Institute, Trinity \\ College, Dublin 2, Republic of Ireland: ${ }^{3}$ Nutritional Sciences, Department of Food Science and Technology, \\ University College, Cork, Ireland: ${ }^{4}$ Northern Ireland Centre for Diet and Health (NICHE), University of Ulster, \\ Coleraine, Co. Londonderry, BT52 1SA, Northern Ireland
}

\begin{abstract}
Objective: To obtain measured anthropometric data for weight, height and other parameters not previously measured in the Irish population such as waist and hip circumferences and body composition.

Design: A cross-sectional survey. Weight, height, waist circumference, hip circumference and body composition were measured according to standard procedures.

Setting: Northern Ireland and the Republic of Ireland, 1997-1999.

Subjects: Random representative sample of 1379 adults aged 18-64 years.

Results: With the exception of body fat, all anthropometric values were significantly higher for men than women $(P<0.001)$. All measurements were significantly higher in the 36-50-year-old age group compared with 18-35 year olds. Height was the exception, which decreased significantly with age $(P<0.05)$. Weight, height and body mass index (BMI) have increased in Ireland since last measured in 1988 and in 1990. Over the last decade, obesity has increased in men 2.5 fold from $8 \%$ to $20 \%$ and in women by 1.25 fold from $13 \%$ to $16 \%$. Significantly more women have a normal BMI than men $(50.4 \%$ vs. $33.3 \% ; P<0.05)$. Cut-off points for a high waist circumference and high waist-to-hip ratio identified $47 \%$ and $33 \%$ of the population, respectively, to be at an increased risk for cardiovascular disease. Social class did not have any significant effect on mean BMI. Location of residence influenced BMI but not in any consistent manner. Ex-smokers had a significantly higher BMI than nonsmokers and smokers $(P<0.05)$.

Conclusions: A revision of current recommendations for combating obesity is warranted to improve the health of the Irish population. Further research is needed to identify the factors that have contributed to the dramatic increase in the prevalence of obesity in men over the last decade and have resulted in a higher prevalence of obesity in men than in women.
\end{abstract}

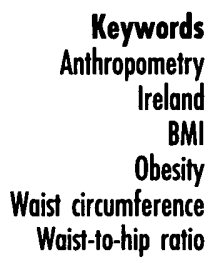

Overweight and obesity are rapidly growing problems and are of major public health concern on a global basis. Obesity is a major risk factor for many metabolic disorders and non-communicable diseases such as diabetes, cardiovascular disease (CVD) and certain types of cancer ${ }^{1}$. Much of the increase in obesity has been attributed to high fat diets and sedentary lifestyles currently prevalent in Western countries ${ }^{2,3}$. National surveys in the UK and USA have shown a rapid rise in the prevalence of obesity in the last 10 years ${ }^{4,5}$. It has been reported that, in Australia, the population is gaining approximately 1 gram per day of body weight ${ }^{6}$. Recently, published data for
Ireland suggests that there has been no change in the prevalence of obesity since $1990^{7-9}$. However, these data were self-reported which tends to be biased towards overreporting of height and underreporting of weight, resulting in very conservative estimates of obesity ${ }^{7,10}$.

The present study set out to obtain up-to-date data on several anthropometric parameters for the populations of Northern Ireland and the Republic of Ireland and to include measurements of waist circumference, hip circumference and body composition, which have not previously been measured for these populations. In addition to body mass index (BMI), waist and hip 
measurements can be used to assess the need for weight management and predict the risks for cardiovascular disease in the population. Numerous publications have demonstrated that central adiposity measured by waist circumference and waist-to-hip ratio (WHR) is closely associated with risk factors that may ultimately lead to cardiovascular disease ${ }^{11-15}$. Cut-off points for waist circumference and waist-to-hip ratio have been defined to identify those people at a greater risk of having one or more cardiac risk factors such as high blood pressure, raised plasma lipids and increased insulin resistance ${ }^{16-18}$. These risk assessments are of utmost importance considering that cardiovascular disease is the single largest cause of death in Ireland, accounting for $43 \%$ of all deaths in $1997^{19}$.

\section{Methodology}

\section{Study sample}

The North/South Ireland Food Consumption Survey (NSIFCS) was conducted between 1997 and 1999 and comprised of a random representative sample of 1379 adults aged 18-64 years of the populations in the Republic of Ireland and Northern Ireland. Data on food intake, health and lifestyle, physical activity, attitudes to food and health and anthropometry were collected. A detailed description of the methodology of this survey has been published elsewhere in this supplement ${ }^{20}$.

\section{Antbropometric measurements}

All body measurements were performed in duplicate with the exception of height and body composition. Body weight was measured with the subject dressed in light clothing, after voiding and having removed keys and coins from pockets, using a Seca Alpha 770 digital scale (CMS Weighing Equipment Ltd, London, UK), calibrated in $100 \mathrm{~g}$ intervals. The surface on which the measurement was taken was recorded. Height was measured using a Leicester height measure to the nearest $0.1 \mathrm{~cm}$ (CMS Weighing Equipment Ltd, London, UK). The respondent removed shoes and stood upright ensuring that the heels, buttocks and scapulae were in contact with the backboard and the head positioned in the Frankfort Plane ${ }^{21}$. The respondent was asked to relax his/her shoulders, inhale and exhale before the height was measured. Waist and hip circumferences were measured in duplicate using a narrow metal Raybone Chesterman measuring tape calibrated in $1 \mathrm{~mm}$ intervals (CMS Weighing Equipment Ltd, London, UK). The waist was measured on the subject's left-hand side at the mid-point between the lowest point on the rib cage and the top of the iliac crest on the mid-auxiliary. When possible, the waist circumference was measured at the naked site. The hips were measured over the widest part of the buttocks at the level of the trochanters ${ }^{22}$. Body composition was measured using a Bodystat ${ }^{\circledR} 1500$ bioelectrical impedance analyser using the procedures recommended by the manufacturer (Bodystat Ltd, Douglas, Isle of Man, UK). After voiding, the subject lay supine for five minutes prior to the test. Exercise activities, alcohol and caffeine consumption and the time of last eating occasion were recorded for the previous 24 hours. Resting ECG disposable electrodes (Blue Sensor, Medicotest, Ltd, UK) were placed firmly on the right hand and the right foot, then body fat, lean body mass and body water were analysed for the subject.

BMI was calculated using weight and height (weight/ height ${ }^{2}$ ) and categorised according to World Health Organization (WHO) recommendations ${ }^{1}$. Two risk categories of waist circumference were used to identify subjects who were at an increased risk (men $\geq 94 \mathrm{~cm}$, women $\geq 80 \mathrm{~cm}$ ) or a high risk (men $\geq 102 \mathrm{~cm}$, women $\geq 88 \mathrm{~cm}$ ) of having at least one major cardiac risk factor $^{16,17}$. A high risk of cardiovascular disease was also assessed using cut-off points for WHR, defined as $\geq 0.95$ for men and as $\geq 0.80$ for women as used by other authors $^{16,18}$. The database from the Irish National Nutrition Survey (INNS) was re-analysed for 18-64 year olds, thus allowing for direct comparisons with the current study $^{23}$.

\section{Statistical analysis}

All statistical analyses were carried out using SPSS $^{\circledR}$ Base 9.0 (SPSS Inc., Chicago, IL). The mean and standard deviation (SD) were calculated for weight, height, BMI, waist and hip circumferences, WHR and percentage body fat. As all measurements were normally distributed, independent $t$-tests and one-way analysis of variance (ANOVA) were used to test for significant differences in mean anthropometric measurements between gender, age groups and lifestyle factors. Significance was defined as $P<0.05$. When ANOVA tables identified significant differences between age groups and lifestyle factors, post boc tests were employed to identify which groups were significantly different. Equality of variance was assessed using Levene's test and that determined which post boc test to use $\mathrm{u}^{24}$. For groups of equal variance, significant differences between groups were tested using the Scheffe post boc test (unless otherwise stated) ${ }^{24}$. When the Levene test was not satisfied and in addition the F-max score was greater than 3, the Tamhane post boc test for unequal variance was used to identify significant differences between groups ${ }^{24}$. Cross tabulation identified the proportion of subjects in each of the BMI categories and the proportion of subjects in the defined risk categories for waist circumference and WHR, which were expressed as percentages. Significant differences between age groups and gender were tested using Chi-squared analysis ${ }^{25}$.

\section{Results}

A complete set of anthropometric measurements was obtained for $73.2 \%$ of the sample. Response to each of the 
Table 1 Mean anthropometric measurements and standard deviations (SDs) in Irish adults according to sex and age

\begin{tabular}{|c|c|c|c|c|c|c|c|c|c|c|c|c|c|}
\hline & & \multicolumn{3}{|c|}{ All ages $18-64$ years } & \multicolumn{3}{|c|}{$18-35$ years } & \multicolumn{3}{|c|}{$36-50$ years } & \multicolumn{3}{|c|}{$51-64$ years } \\
\hline & & Mean & SD & $n$ & Mean & SD & $n$ & Mean & SD & $n$ & Mean & SD & $n$ \\
\hline All & $\begin{array}{l}\text { Weight }(\mathrm{kg}) \\
\text { Height }(\mathrm{m}) \\
\text { BMI }\left(\mathrm{kg} \mathrm{m}^{-2}\right) \\
\text { Waist circumference }(\mathrm{cm}) \\
\text { Hip circumference }(\mathrm{cm}) \\
\text { Waist-to-hip ratio } \\
\text { Bodv fat }(\%)\end{array}$ & $\begin{array}{c}74.9 \\
1.68 \\
26.3 \\
87.0 \\
102.8 \\
0.84 \\
27.8\end{array}$ & $\begin{array}{l}(15.0) \\
(0.09) \\
(4.5) \\
(13.3) \\
(9.0) \\
(0.09) \\
(8.8)\end{array}$ & $\begin{array}{l}1369 \\
1311 \\
1311 \\
1120 \\
1118 \\
1118 \\
1098\end{array}$ & $\begin{array}{c}72.5^{\mathrm{a}} \\
1.70^{\mathrm{a}} \\
25.04^{\mathrm{a}} \\
83.3^{\mathrm{a}} \\
101.2^{\mathrm{a}} \\
0.82^{\mathrm{a}} \\
23.9^{\mathrm{a}}\end{array}$ & $\begin{array}{l}(14.9) \\
(0.10) \\
(4.1) \\
(12.1) \\
(8.6) \\
(0.08) \\
(8.3)\end{array}$ & $\begin{array}{l}518 \\
505 \\
505 \\
442 \\
441 \\
441 \\
441\end{array}$ & $\begin{array}{c}75.7^{\mathrm{b}} \\
1.67^{\mathrm{b}} \\
26.8^{\mathrm{b}} \\
87.8^{\mathrm{b}} \\
103.5^{\mathrm{b}} \\
0.5^{\mathrm{b}} \\
29.3^{\mathrm{b}}\end{array}$ & $\begin{array}{l}(15.3) \\
(0.09) \\
(4.4) \\
(13.5) \\
(8.8) \\
(0.09) \\
(7.9)\end{array}$ & $\begin{array}{l}520 \\
498 \\
498 \\
418 \\
418 \\
418 \\
420\end{array}$ & $\begin{array}{c}77.4^{\mathrm{b}} \\
1.67^{\mathrm{b}} \\
27.7^{\mathrm{c}} \\
91.9^{\mathrm{c}} \\
104.5^{\mathrm{b}} \\
0.88^{\mathrm{c}} \\
32.3^{\mathrm{c}}\end{array}$ & $\begin{array}{l}(14.3) \\
(0.09) \\
(4.6) \\
(12.9) \\
(9.3) \\
(0.09) \\
(8.6)\end{array}$ & $\begin{array}{l}331 \\
308 \\
308 \\
260 \\
259 \\
259 \\
237\end{array}$ \\
\hline Men & $\begin{array}{l}\text { Weight }(\mathrm{kg}) \\
\text { Height }(\mathrm{m}) \\
\text { BMI }\left(\mathrm{kg} \mathrm{m}^{-2}\right) \\
\text { Waist circumference }(\mathrm{cm}) \\
\text { Hip circumference }(\mathrm{cm})\end{array}$ & $\begin{array}{c}82.9^{\star} \\
1.75^{*} \\
26.9^{*} \\
94.3^{*} \\
104.1^{*}\end{array}$ & $\begin{array}{l}(13.3) \\
(0.07) \\
(4.0) \\
(11.3) \\
(7.6)\end{array}$ & $\begin{array}{l}655 \\
613 \\
613 \\
492 \\
491\end{array}$ & $\begin{array}{c}81.0^{\mathrm{a}} \\
1.77^{\mathrm{a}} \\
25.8^{\mathrm{a}} \\
90.3^{\mathrm{a}} \\
103.0^{\mathrm{a}}\end{array}$ & $\begin{array}{l}(13.3) \\
(0.07) \\
(3.6) \\
(10.5) \\
(7.8)\end{array}$ & $\begin{array}{l}249 \\
240 \\
240 \\
198 \\
197\end{array}$ & $\begin{array}{c}84.8^{\mathrm{b}} \\
1.75^{\mathrm{b}} \\
27.7^{\mathrm{b}} \\
96.6^{\mathrm{b}} \\
105.4^{\mathrm{b}}\end{array}$ & $\begin{array}{l}(13.6) \\
(0.06) \\
(4.3) \\
(11.7) \\
(7.7)\end{array}$ & $\begin{array}{l}235 \\
217 \\
217 \\
167 \\
167\end{array}$ & $\begin{array}{c}83.2^{\mathrm{ab}} \\
1.73^{\mathrm{b}} \\
27.6^{\mathrm{b}} \\
97.6^{\mathrm{b}} \\
104.1^{\mathrm{ab}}\end{array}$ & $\begin{array}{l}(12.6) \\
(0.07) \\
(3.6) \\
(10.1) \\
(6.9)\end{array}$ & $\begin{array}{l}171 \\
156 \\
156 \\
127 \\
127\end{array}$ \\
\hline & $\begin{array}{l}\text { Waist-to-hip ratio } \\
\text { Body fat }(\%)\end{array}$ & $\begin{array}{l}0.91^{*} \\
21.2^{*}\end{array}$ & $\begin{array}{l}(0.07) \\
(5.8)\end{array}$ & $\begin{array}{l}491 \\
495\end{array}$ & $\begin{array}{l}0.88^{\mathrm{a}} \\
17.7^{\mathrm{a}}\end{array}$ & $\begin{array}{l}(0.06) \\
(5.0)\end{array}$ & $\begin{array}{l}197 \\
203\end{array}$ & $\begin{array}{l}0.92^{\mathrm{b}} \\
22.7^{\mathrm{b}}\end{array}$ & $\begin{array}{l}(0.07) \\
(5.3)\end{array}$ & $\begin{array}{l}167 \\
177\end{array}$ & $\begin{array}{l}0.94^{c} \\
24.0^{c}\end{array}$ & $\begin{array}{l}(0.06) \\
(3.8)\end{array}$ & $\begin{array}{l}127 \\
115\end{array}$ \\
\hline Women & $\begin{array}{l}\text { Weight }(\mathrm{kg}) \\
\text { Height }(\mathrm{m}) \\
\text { BMI }\left(\mathrm{kg} \mathrm{m} \mathrm{m}^{-2}\right) \\
\text { Waist circumference }(\mathrm{cm}) \\
\text { Hip circumference }(\mathrm{cm}) \\
\text { Waist-to-hip ratio } \\
\text { Body fat }(\%)\end{array}$ & $\begin{array}{c}67.5 \\
1.62 \\
25.8 \\
81.2 \\
101.8 \\
0.80 \\
33.2\end{array}$ & $\begin{array}{l}(12.5) \\
(0.06) \\
(4.8) \\
(11.7) \\
(9.8) \\
(0.07) \\
(7.1)\end{array}$ & $\begin{array}{l}714 \\
698 \\
698 \\
628 \\
627 \\
627 \\
603\end{array}$ & $\begin{array}{l}64.6^{\mathrm{a}} \\
1.63^{\mathrm{a}} \\
24.4^{\mathrm{a}} \\
77.5^{\mathrm{a}} \\
99.6^{\mathrm{a}} \\
0.78^{\mathrm{a}} \\
29.2^{\mathrm{a}}\end{array}$ & $\begin{array}{l}(11.6) \\
(0.06) \\
(4.3) \\
(10.2) \\
(8.9) \\
(0.06) \\
(6.7)\end{array}$ & $\begin{array}{l}269 \\
265 \\
265 \\
244 \\
244 \\
244 \\
238\end{array}$ & $\begin{array}{c}68.1^{\mathrm{b}} \\
1.62^{\mathrm{b}} \\
26.1^{\mathrm{b}} \\
81.9^{\mathrm{b}} \\
102.3^{\mathrm{b}} \\
0.80^{\mathrm{b}} \\
34.1^{\mathrm{b}}\end{array}$ & $\begin{array}{l}(12.3) \\
(0.06) \\
(4.4) \\
(11.2) \\
(9.3) \\
(0.06) \\
(5.7)\end{array}$ & $\begin{array}{l}285 \\
281 \\
281 \\
251 \\
251 \\
251 \\
243\end{array}$ & $\begin{array}{c}71.1^{\mathrm{b}} \\
1.60^{\mathrm{c}} \\
27.8^{\mathrm{c}} \\
86.6^{\mathrm{c}} \\
104.9^{\mathrm{c}} \\
0.82^{\mathrm{c}} \\
39.1^{\mathrm{c}}\end{array}$ & $\begin{array}{l}(13.3) \\
(0.06) \\
(5.5) \\
(13.0) \\
(11.2) \\
(0.07) \\
(5.6)\end{array}$ & $\begin{array}{l}160 \\
152 \\
152 \\
133 \\
132 \\
132 \\
122\end{array}$ \\
\hline
\end{tabular}

* Denotes significant differences found between men and women for each of the mean anthropometric measurements at $P<0.001$.

abc Different superscripts within a row denote significant differences between age groups at $P<0.05$.

individual measurements varied. Of the 1379 subjects who participated in the survey, weight was obtained for $99 \%$, height $95 \%$, WHR $81 \%$ and body fat $79.6 \%$.

Table 1 summarises the mean anthropometric results, for all subjects combined, all males, all females and by three age groups. For almost all of the anthropometric variables, for both males and females, significantly higher $(P<0.05)$ values were observed in the 36-50-year-old age group compared with those aged $18-35$ years. Height was the exception in that there was a small but statistically significant $(P<0.05)$ decline across these age groups.

In men, the majority of the anthropometric measurements did not significantly increase further in the 51-64year-old age group, compared with the younger age groups, with the exception of waist-to-hip ratio and percentage body fat. These measurements were significantly greater $(P<0.05)$ in the 51-64-year-old men. A slight decrease in both weight and hip measurements occurred after 50 years of age in men and these were the only measurements that were not significantly higher in the 51-64-year-old age group compared with 18-35 year olds. In women, all of the anthropometric measurements, with the exception of weight and height, were significantly greater $(P<0.05)$ in the 51-64-year-old age group. Height showed a small but significant $(P<0.05)$ decline. For all age groups combined (18-64 years), the anthropometric values were significantly higher $(P<0.001)$ for men than for women with the exception of body fat, where, as expected, females had a significantly higher value.

The percentage of the population in the different BMI categories is given in Table 2. For the total population, less than $1 \%$ were underweight, $42.4 \%$ were in the normal range, $39 \%$ were pre-obese (overweight) and $17.8 \%$ were obese. The majority of the obese subjects were in class I obesity (BMI $=30.0-34.9 \mathrm{~kg} \mathrm{~m}^{-2}$ ) and less than $1 \%$ were morbidly obese (BMI $\left.\geq 40 \mathrm{~kg} \mathrm{~m}^{-2}\right)^{1}$. For all age groups, a higher proportion of women were in the normal BMI category $(P<0.05)$. The proportion of the total population in the normal category decreased significantly $(P<$ 0.001 ) with increasing age. Conversely, in the pre-obese and obese categories, the proportions increased significantly up to the 36-50-year-old age group $(P<0.05)$. Only in females in the obese category did this increase significantly in the 51-64-year-old age group. Due to the small number of subjects in obese classes I, II and III, no comparisons were made.

Waist circumference and WHR are presented in Table 3, where the data are expressed as a percentage of the population at varying levels of risk for cardiovascular disease as previously defined ${ }^{16}$. In both males and females, the percentage of subjects in the risk categories increased with increasing age group for both waist circumference and WHR. For the total population combined and for each gender, there was a significantly greater proportion of both the 36-50 and 51-64 year olds in the increased and high risk categories of waist circumference, compared with 18-35 year olds $(P<$ $0.05)$. Contrary to trends in BMI, significantly more men were in the normal risk category of WHR than women $(P<0.001)$, while significantly more women were in the increased risk category $(P<0.001)$. The proportion of both men and women in the increased risk category of WHR increased significantly between the 18-35 year age 


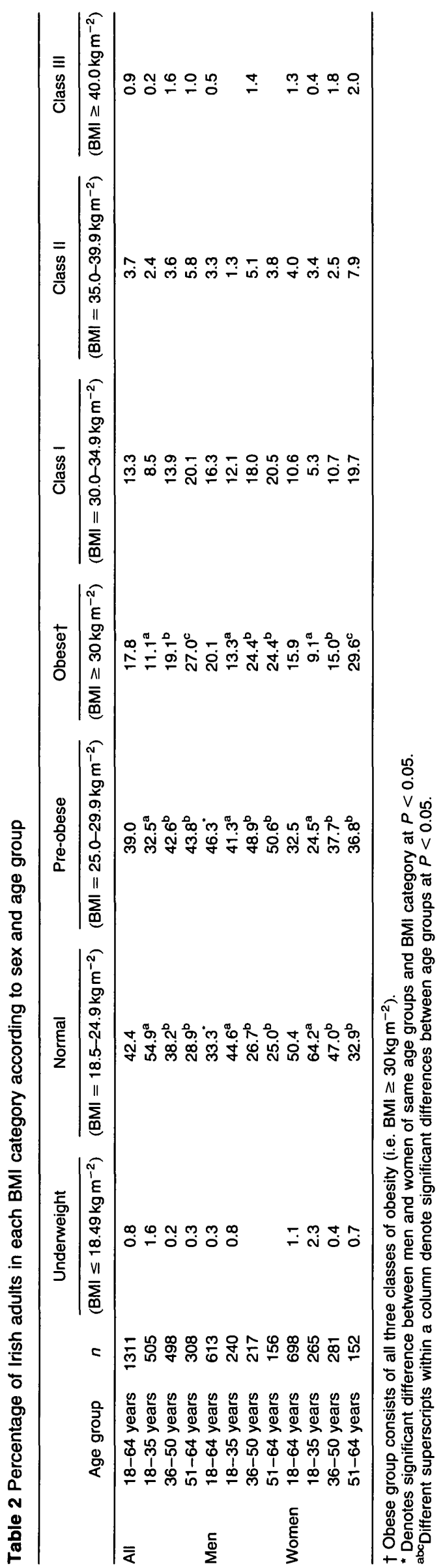

group and the 36-50 year age group $(P<0.05)$. This increased significantly in the 51-64 year age group for men only.

Table 4 examines the association of BMI with socioeconomic, demographic and lifestyle factors. Social class was not significantly associated with mean BMI in men or women, in any of the age groups. Location of residence appeared to influence BMI but not in any consistent manner across age and sex groups. In women, there appears to be a difference in mean BMI between those residing in the countryside and the city. For all subjects combined, ex-smokers (daily) had a significantly higher mean BMI $(P<0.05)$ compared with non-smokers, who in turn had a significantly higher mean BMI $(P<0.05)$ than smokers.

\section{Discussion}

This is the first survey of its kind to have combined anthropometry data from Northern Ireland and the Republic of Ireland using the same protocols and methodology. The mean anthropometric data from both the North and the South did not differ significantly from each other with respect to weight, height and BMI. The entire N/S database can therefore be directly compared with previous surveys (Irish National Nutrition Survey (INNS) and Diet, Lifestyle and Health in Northern Ireland (DLHNI)) to track any changes that have occurred with time $^{23,26}$ (Table 5).

Table 5 compares the current data with results from previous studies and indicates that mean weight, height and BMI have increased in both men and women over the last 10-12 years. Weight appears to have increased more in men than in women, with an approximate weight gain of $0.55 \mathrm{~kg}$ and $0.33 \mathrm{~kg}$ per year, respectively, since the INNS and the DLHNI survey. This can be translated into the entire population gaining approximately 1 gram per day of body weight, a figure precisely similar to the population of Australia ${ }^{6}$. Mean height in males and females has also increased by approximately $1-2 \mathrm{~cm}$.

Obesity has increased to $17.8 \%$, which represents a 1.7 fold increase compared with INNS data and a 1.5 fold increase compared with the DLHNI survey ${ }^{23,26}$ (Table 5). Obesity in men has increased 2.5 fold from $7.8 \%$ to $20 \%$ over the last decade ${ }^{23}$. The proportion of obese females has increased 1.25 fold, from $12.9 \%$ to $15.9 \%$, in 10 years ${ }^{23}$. In the total sample, the proportion of subjects in the normal category of BMI has decreased from $49.5 \%$ to $42.4 \%$, while the pre-obese $(0.9 \%$ increase $)$ and underweight $(0.9 \%$ decrease) categories have remained relatively unchanged during this time ${ }^{23}$.

A striking finding from these data is that the prevalence of obesity in men has increased more rapidly than in women, with the prevalence of obesity in men (20\%) now exceeding that in women (15.9\%). On a world-wide scale, the prevalence of obesity is generally higher among 
Table 3 Percentage of Irish adults with increasing risk for CVD as defined by waist circumference ${ }^{16,17}$ and WHR ${ }^{18}$ according to sex and age

\begin{tabular}{|c|c|c|c|c|c|c|c|c|}
\hline & \multirow[b]{2}{*}{ Age group } & \multicolumn{4}{|c|}{ Waist circumferencet } & \multicolumn{3}{|c|}{ WHR } \\
\hline & & $n$ & Normal risk & Increased risk & High risk & $n$ & Normal risk & Increased risk \\
\hline All & $\begin{array}{l}18-64 \text { years } \\
18-35 \text { years } \\
36-50 \text { years } \\
51-64 \text { years }\end{array}$ & $\begin{array}{r}1120 \\
442 \\
418 \\
260\end{array}$ & $\begin{array}{l}52.4 \\
69.0^{\mathrm{a}} \\
45.0^{\mathrm{b}} \\
36.2^{\mathrm{b}}\end{array}$ & $\begin{array}{l}24.1 \\
17.0^{\mathrm{a}} \\
29.7^{\mathrm{b}} \\
27.3^{\mathrm{b}}\end{array}$ & $\begin{array}{l}23.5^{\mathrm{a}} \\
14.0^{\mathrm{a}} \\
25.4^{\mathrm{b}} \\
36.5^{\mathrm{c}}\end{array}$ & $\begin{array}{r}1118 \\
441 \\
418 \\
259\end{array}$ & $\begin{array}{l}66.6 \\
79.8^{\mathrm{a}} \\
62.4^{\mathrm{b}} \\
51.0^{\mathrm{c}}\end{array}$ & $\begin{array}{l}33.4 \\
20.2^{\mathrm{a}} \\
37.6^{\mathrm{b}} \\
49.0^{\mathrm{c}}\end{array}$ \\
\hline Men & $\begin{array}{l}18-64 \text { years } \\
18-35 \text { years } \\
36-50 \text { years } \\
51-64 \text { years }\end{array}$ & $\begin{array}{l}492 \\
198 \\
167 \\
127\end{array}$ & $\begin{array}{l}52.4 \\
69.2^{\mathrm{a}} \\
43.1^{\mathrm{b}} \\
38.6^{\mathrm{b}}\end{array}$ & $\begin{array}{l}24.4^{a} \\
17.7^{a} \\
29.9^{b} \\
27.6^{b}\end{array}$ & $\begin{array}{l}23 . .^{a} \\
13.1^{a} \\
26.9^{b} \\
33.9^{b}\end{array}$ & $\begin{array}{l}491 \\
197 \\
167 \\
127\end{array}$ & $\begin{array}{l}77.8^{\star} \\
89.3^{\mathrm{a}} \\
77.8^{\mathrm{b}} \\
59.8^{\mathrm{c}}\end{array}$ & $\begin{array}{l}22.2^{*} \\
10.7^{a} \\
22.2^{b} \\
40.2^{c}\end{array}$ \\
\hline Women & $\begin{array}{l}18-64 \text { years } \\
18-35 \text { years } \\
36-50 \text { years } \\
51-64 \text { years }\end{array}$ & $\begin{array}{l}628 \\
244 \\
251 \\
133\end{array}$ & $\begin{array}{l}52.4 \\
68.9^{a} \\
46.2^{b} \\
33.8^{c}\end{array}$ & $\begin{array}{l}23.9^{a} \\
16.4^{a} \\
29.5^{b} \\
27.1^{b}\end{array}$ & $\begin{array}{l}23.7^{\mathrm{b}} \\
14.8^{\mathrm{b}} \\
24.3^{\mathrm{b}} \\
39.1^{\mathrm{c}}\end{array}$ & $\begin{array}{l}627 \\
244 \\
251 \\
132\end{array}$ & $\begin{array}{l}57.9^{\star} \\
72.1^{a} \\
52.2^{b} \\
42.4^{b}\end{array}$ & $\begin{array}{l}42.1^{\star} \\
27.9^{a} \\
47.8^{b} \\
57.6^{b}\end{array}$ \\
\hline
\end{tabular}

† Waist circumference - normal risk: $<94 \mathrm{~cm}$ for men and $<80 \mathrm{~cm}$ for women; increased risk: $94-101.9 \mathrm{~cm}$ for men and $80-87.9 \mathrm{~cm}$ for women; high risk: $\geq 102 \mathrm{~cm}$ for men and $\geq 88 \mathrm{~cm}$ for women.

$\ddagger$ WHR - normal risk: $<0.95$ for men and $<0.80$ for women; increased risk: $\geq 0.95$ for men and $\geq 0.80$ for women.

Denotes significant difference between men and women, $P<0.05$.

abc Different superscripts within a column denote significant differences between age groups at $P<0.05$.

Table 4 Mean BMI values and standard deviations (SDs) in Irish adults (18-64 years) by sex and lifestyle factors

\begin{tabular}{|c|c|c|c|c|c|c|c|c|c|}
\hline & \multicolumn{3}{|c|}{ All } & \multicolumn{3}{|c|}{ Men } & \multicolumn{3}{|c|}{ Women } \\
\hline & Mean & SD & $n$ & Mean & SD & $n$ & Mean & SD & $n$ \\
\hline \multicolumn{10}{|l|}{ Social class } \\
\hline Professional & 25.9 & (3.8) & 126 & 26.9 & (3.8) & 57 & 25.1 & (3.6) & $6 s$ \\
\hline Managerial/Technical & 26.6 & (4.3) & 427 & 27.3 & (3.8) & 198 & 25.9 & (4.6) & 229 \\
\hline Non-manual & 26.1 & (4.8) & 237 & 27.1 & (4.7) & 82 & 25.6 & (4.9) & 155 \\
\hline Skilled manual & 26.6 & (4.4) & 246 & 27.0 & (3.9) & 141 & 26.0 & (5.0) & 105 \\
\hline Semi-skilled & 26.1 & (4.6) & 159 & 26.2 & (4.3) & 74 & 26.1 & (4.9) & 85 \\
\hline Unskilled & 26.8 & (5.0) & 44 & 26.9 & (3.2) & 28 & 26.7 & (7.2) & 16 \\
\hline Student & 24.1 & (3.0) & 32 & 24.7 & (2.8) & 19 & 23.3 & (3.3) & 13 \\
\hline \multicolumn{10}{|l|}{ Location of residence } \\
\hline Open country \& village & $27.0^{\mathrm{a}}$ & $(4.6)$ & 458 & 27.2 & $(4.2)$ & 221 & $26.8^{a}$ & (4.9) & 237 \\
\hline Small town (1500-9999) & $26.0^{\mathrm{ab}}$ & (4.1) & 146 & 27.2 & (3.8) & 69 & $24.9^{\mathrm{b}}$ & (4.0) & 77 \\
\hline Large town $(>10000)$ & $26.7^{\mathrm{a}}$ & (4.4) & 220 & 27.1 & (3.4) & 104 & $26.4^{\mathrm{ab}}$ & (5.0) & 116 \\
\hline City & $25.7^{b}$ & (4.4) & 487 & 26.4 & (4.1) & 219 & $25.0^{\mathrm{b}}$ & (4.6) & 268 \\
\hline \multicolumn{10}{|l|}{ Smoking habits } \\
\hline Smoker & $25.2^{\mathrm{a}}$ & (3.9) & 342 & $25.9^{\mathrm{a}}$ & (3.7) & 167 & $24.5^{\mathrm{a}}$ & $(4.0)$ & 175 \\
\hline Smoker (occasionally) & $25.5^{\mathrm{ac}}$ & (3.7) & 80 & $26.6^{\mathrm{ab}}$ & (3.4) & 33 & $24.6^{c}$ & (3.6) & 47 \\
\hline Ex-smoker (daily) & $27.9^{\mathrm{b}}$ & (4.3) & 182 & $28.1^{\mathrm{b}}$ & (3.6) & 108 & $27.6^{\mathrm{b}}$ & (5.1) & 74 \\
\hline Ex-smoker (occasionally) & $26.4^{a b c}$ & (3.9) & 133 & $27.6^{\mathrm{ab}}$ & (3.4) & 53 & $25.7^{\mathrm{abc}}$ & (4.0) & 80 \\
\hline Never smoked & $26.7^{c}$ & (4.9) & 561 & $27.0^{\mathrm{ab}}$ & (4.3) & 244 & $26.4^{\mathrm{bc}}$ & (5.3) & 317 \\
\hline
\end{tabular}

abc Different superscripts within a column denote significant differences in lifestyle factors at $P<0.05$.

Table 5 Comparison of mean anthropometric measurements in NSIFCS with previous large-scale nutrition surveys in the Republic of Ireland and the UK

\begin{tabular}{|c|c|c|c|c|c|c|c|c|c|c|c|c|c|c|}
\hline & \multirow[b]{3}{*}{ Age range } & \multirow[b]{3}{*}{ Obesity (\%) } & \multicolumn{6}{|c|}{ Men } & \multicolumn{6}{|c|}{ Women } \\
\hline & & & \multicolumn{2}{|c|}{ Weight } & \multicolumn{2}{|c|}{ Height } & \multicolumn{2}{|c|}{$\mathrm{BMI}$} & \multicolumn{2}{|c|}{ Weight } & \multicolumn{2}{|c|}{ Height } & \multicolumn{2}{|c|}{$\mathrm{BMI}$} \\
\hline & & & $\mathrm{kg}$ & $n$ & $\mathrm{~m}$ & $n$ & $\mathrm{~kg} \mathrm{~m}^{-2}$ & $n$ & $\mathrm{~kg}$ & $n$ & $m$ & $n$ & $\mathrm{~kg} \mathrm{~m}^{-2}$ & $n$ \\
\hline $\begin{array}{l}\text { NSIFCS } \\
\text { INNS, } 1990^{23} \\
\text { DNSBA, } 1990^{36} \\
\text { DLHNI, } 1988^{26}\end{array}$ & $\begin{array}{l}18-64 \text { years } \\
18-64 \text { years } \\
16-64 \text { years } \\
16-64 \text { years }\end{array}$ & $\begin{array}{l}17.8 \\
10.7 \\
10^{\star} \\
12\end{array}$ & $\begin{array}{l}82.9 \\
78.1 \\
75.9 \\
75.3\end{array}$ & $\begin{array}{r}655 \\
256 \\
1194 \\
265\end{array}$ & $\begin{array}{l}1.75 \\
1.74 \\
1.75 \\
1.74\end{array}$ & $\begin{array}{r}613 \\
256 \\
1160 \\
265\end{array}$ & $\begin{array}{l}26.9 \\
25.7 \\
24.9 \\
24.9\end{array}$ & $\begin{array}{r}613 \\
256 \\
1158 \\
265\end{array}$ & $\begin{array}{l}67.5 \\
64.8 \\
64.3 \\
62.9\end{array}$ & $\begin{array}{r}714 \\
334 \\
1189 \\
341\end{array}$ & $\begin{array}{l}1.62 \\
1.61 \\
1.62 \\
1.60\end{array}$ & $\begin{array}{r}698 \\
334 \\
1163 \\
341\end{array}$ & $\begin{array}{l}25.8 \\
24.9 \\
24.6 \\
24.6\end{array}$ & $\begin{array}{r}698 \\
334 \\
1161 \\
341\end{array}$ \\
\hline
\end{tabular}

* Calculated as $\mathrm{BMI}>30 \mathrm{~kg} \mathrm{~m}^{-2}$. 
women than in men, with the exception of Finland and The Netherlands ${ }^{1}$. In The Netherlands a similar prevalence of obesity was reported for men and women ( $8 \%$ for both) in 1995, whereas in Finland a slightly higher prevalence of obesity has been found in men for the last 15 years $(14 \% \text { men; } 11 \% \text { women })^{1}$. These trends are of considerable importance with respect to public health. Given that the prevalence of obesity in men has increased so rapidly and that obesity is an independent risk factor for heart disease ${ }^{4}$, which results in $23 \%$ of deaths in Irish men aged up to 65 years $^{19}$, this dramatic increase in male obesity amplifies the public health concerns regarding obesity.

The changes in the BMI profile of the population may have occurred in the following manner. The decrease in the proportion of the population in the normal BMI category of 7.1 percentage points and the similar increase of 7.1 percentage points in the obese category suggest that some of the formerly normal weight individuals have become overweight (pre-obese), while some of the overweight individuals have become obese. This has resulted in the perception that the pre-obese (overweight) BMI category has remained unchanged whereas actually it has been in a constant state of flux but with no net change. Similar findings have been observed in the USA, where the percentage of people in the pre-obese category has remained relatively unchanged with only a $1.5 \%$ difference between 1962 and 1994, while obesity has increased 1.5 fold from 1980 to $1994^{5}$.

The Department of Health and Children in the Republic of Ireland proposed recommendations for a reduction in both overweight (pre-obese) and obesity by $10 \%$ by 2005 and the Department of Health in the UK recommended a reduction in obesity of $25 \%$ and $33 \%$ for men and women, respectively ${ }^{27,28}$. Given that the prevalence of obesity has increased by $67 \%$, a review of these recommendations is therefore warranted. From these data, it appears that a turnover of those occupying the pre-obese group will not be noticed if the relative size of the pre-obese group does not change. For future recommendations, attention must be focused on the normal BMI category. Before proposing modifications to these recommendations, additional analysis is required to identify and characterise the individuals in the pre-obese group and assess their risk of becoming the next obese generation. Only then can recommendations be specifically targeted at reversing the current trend towards obesity and perhaps allow an increase in the relative size of the normal BMI category.

A decrease of energy intake, a higher proportion of dietary energy derived from fat and a more sedentary lifestyle have been shown to contribute to the increasing prevalence of obesity ${ }^{2,3}$. McGowan et al. revealed that overall energy intakes in Ireland did not change remarkably in the last $10-12$ years while Harrington et al. showed that the percentage food energy from fat was lowest in the 51-64-year-old age group ${ }^{29,30}$. Physical activity data analysed by Livingstone $e t$ al. have shown that there is a reduced total work activity and recreational activity in the obese group along with more TV viewing than in the non-obese ${ }^{31}$. However, all of these findings must be interpreted with some caution, since the obese are more inclined to underreport energy intakes and fat intakes ${ }^{32-34}$. Furthermore, these physical activity data are cross-sectional and do not necessarily reflect the longterm overall patterns of activity. Further investigation is required to identify the groups that need targeting and the approaches that should be followed so that the population might adopt future recommendations.

Recently published data from the WHO MONICA project compared waist and hip circumferences and waist-to-hip ratios in 19 different populations ${ }^{35}$. The mean waist circumference, hip circumference and WHR for men and women in this survey were comparable to those measured for many of the countries examined in the project. The limitation of these comparisons is that although the data from the MONICA project were published recently, the measurements were taken nearly 10 years ago.

In Table 3, the categories of increased risk and high risk of waist circumference represent a 1-2.5 times and 2-4.5 times increased risk, respectively, of having one or more major cardiac risk factors ${ }^{16,17}$. Approximately half of the sample is at a greater risk (increased risk and high risk combined $47.6 \%$ ) of having at least one major risk factor for cardiovascular disease. The high-risk category (23.5\%) corresponds with the level at which symptoms of breathlessness and arthritis begins to develop due to overweight ${ }^{16}$. The group of subjects in the increased risk category must be discouraged from further weight gain and an increase in waist circumference towards the highrisk category. WHR cut-off points indicated that approximately one-third of the population was at an increased risk for cardiovascular disease risk factors. Waist circumference seems to identify a greater proportion of the population that is above normal risk compared with WHR. However, the identification of risk using waist circumference is population-specific and depends on many issues including levels of overweight and obesity ${ }^{1}$. Therefore both waist circumference and WHR require further analyses in conjunction with BMI and body fat to determine the sensitivity of these cut-off points in identifying the subjects at an increased risk of cardiovascular disease in this population.

It is important to note that social class was not significantly associated with mean BMI. The Dietary and Nutritional Survey of British Adults (DNSBA) reported that those in higher social classes had a significantly lower $\mathrm{BMI}^{36}$. It is of interest that there seems to be a countryside/city influence on BMI in females. This group needs further investigation in order to identify what underlying factors are producing this effect. Smoking and BMI demonstrated a strong association, with smokers having 
a significantly lower BMI. It has been suggested that smokers have an altered metabolism or increased metabolic rate resulting in lower body weight and $\mathrm{BMI}^{37}$. However, the hazardous effects of smoking are far more detrimental to health than the ill effects of weight gain due to cessation of smoking, as smokers have higher mortality rates at all levels of $\mathrm{BMI}^{38}$.

The data presented here are first-level analyses and require further investigation to formulate recommendations. However, certain findings are very alarming, such as the dramatic increase in the prevalence of obesity, especially in men, and the proportion of the population with high waist circumference and WHR. The significant increase with age for BMI, waist circumference, WHR and percentage body fat suggests the need to (1) target the young in the population with preventative strategies, to prevent them becoming the next obese generation, and (2) target the older population to attain a healthy body weight and encourage an active lifestyle. In addition to preventative strategies, special attention must be given to identify the factors that have resulted in such a dramatic increase in the prevalence of obesity in men over the last decade.

\section{References}

1 World Health Organization (WHO). Obesity: Preventing and Managing the Global Epidemic. International Obesity Task Force, 3-5 June 1997. Geneva: WHO, 1998.

2 Prentice AM, Jebb SA. Obesity in Britain: gluttony or sloth. Br. Med. J. 1995; 311: 437-9.

3 Wilding $\mathrm{J}$. Science, medicine and the future: obesity treatment. Br. Med. J. 1997; 315: 997-1000.

4 Jebb SA. The Weight of the Nation. Obesity in the UK. A report commissioned by the Bread for Life Campaign. London: The Flour Advisory Bureau Ltd, 1999.

5 Flegal KM, Carroll MD, Kuczmarski RJ, Johnson CL. Overweight and obesity in the United States: prevalence and trends, 1960-1994. Int. J. Obes. 1998; 22: 39-47.

6 Egger G, Swinburn B. An 'ecological' approach to the obesity pandemic. Br. Med. J. 1997; 315: 477-80.

7 Institute of European Food Studies. Results of a Survey on Consumer Attitudes to Pbysical Activity, Body Weight and Health in a Nationally Representative Sample of Irish Adults. Dublin: Trinity College, 1999.

8 Friel S, Nic Gabhainn S, Kelleher C. The National Health $\&$ Lifestyle Surveys. Galway: Health Promotion Unit, Centre for Health Promotion Studies, NUI, 1999.

9 Lee P, Cunningham K. Irish National Nutrition Survey. Dublin: Irish Nutrition \& Dietetic Institute, 1990.

10 Rowland M. Self-reported weight and height. Am. J. Clin. Nutr. 1990; 52: 1125-33.

11 Cox BD, Whichelow MJ, Prevost AT. The development of cardiovascular disease in relation to anthropometric indices and hypertension in British adults. Int. J. Obes. 1998; 22: 966-73.

12 Bertrais S, Balkau B, Vol S, Forhan A, Calvet C, Marre M, Eschwège $E$, the DESIR Study Group. Relationships between abdominal fat distribution and cardiovascular risk factors: an explanation for women's healthier cardiovascular risk profile. Int. J. Obes. 1999; 23: 1085-94.

13 Larsson B, Svärdsudd K, Welin L, Wilhelmsen L, Björntorp P, Tibblin G. Abdominal adipose tissue distribution, obesity, and risk of cardiovascular disease and death: 13 year follow up of participants in the study of men born in 1913. Br. Med.J. 1984; 288: 1401-4.

14 Lapidus L, Bengtsson C, Larsson B, Pennert K, Rybo E, Sjostrom L. Distribution of adipose tissue and risk of cardiovascular disease and death: a 12-year follow up of participants in the population of women in Gothenburg, Sweden. Br. Med. J. 1984; 289: 1257-61.

15 Vanltallie TB. Waist circumference: a useful index in clinical care and health promotion. Nutr. Rev. 1998; 56: 300-13.

16 Lean MEJ, Han TS, Morrison CE. Waist circumference as a measure for indicating need for weight management. $\mathrm{Br}$. Med. J. 1995; 311: 58-61.

17 Han TS, van Leer EM, Seidell JC, Lean MEJ. Waist circumference action levels in the identification of cardiovascular risk factors: prevalence study in a random sample. Br. Med. J. 1995; 311: 1401-5.

18 Croft JB, Keenan NL, Sheridan DP, Wheeler FC, Speers MA Waist-to-hip ratio in a biracial population: measurement, implications and cautions for using guidelines to define high risk for cardiovascular disease. J. Am. Diet. Assoc. 1995; 95: 60-4.

19 Department of Health and Children. The Report of the Cardiovascular Health Strategy Group: Building Healtbier Hearts. Dublin: Government Publications, 1999; 27.

20 Harrington $\mathrm{KE}$, Robson $\mathrm{PJ}$, Kiely $\mathrm{M}$, Livingstone MBE, Lambe J, Gibney MJ. The North/South Ireland Food Consumption Survey: survey design and methodology. Public Health Nutr. 2001; 4(5A): 1037-42.

21 Cameron N. The Measurement of Human Growth. Instrumentation, Surface Landmarks, and Antbropometric Measurements. Kent: Croom Helm, 1984.

22 Flynn MA, Codd MB, Gibney MJ, Keelan ET, Sugrue DD. Indices of obesity and body fat distribution in arteriographically defined coronary artery disease in men. Ir. J. Med. Sci. 1993; 162: 503-9.

23 Irish Nutrition and Dietetic Institute. Unpublished data from the database of the Irish National Nutrition Survey. Dublin: Irish Nutrition and Dietetic Institute, 1990.

24 Coakes SJ, Steed LG. SPSS without Anguish Versions 7.0, 7.5, 8.0 for Windows. Brisbane: John Wiley \& Sons, 1999.

25 Glantz SA. Primer of Biostats, 4th ed. San Francisco, CA: McGraw-Hill, 1981.

26 Barker ME, McClean SI, McKenna PG, et al. Diet Lifestyle and Health in Northern Ireland. Coleraine, Northern Ireland: University of Ulster, 1988.

27 Department of Health and Children. A Health Promotion Strategy: Making the Healthier Choice the Easier Choice. Dublin: Department of Health and Children, 1995.

28 Department of Health. The Health of the Nation. London: Department of Health, 1992.

29 McGowan MJ, Harrington KE, Kiely M, Robson PJ, Livingstone MBE, Gibney MJ. An evaluation of energy intakes and the ratio of energy intake to estimated metabolic rate (EI/BMR ess $)$ in the North/South Ireland Food Consumption Survey. Public Health Nutr. 2001; 4(5A): $1043-50$.

30 Harrington KE, McGowan MJ, Kiely M, Robson PJ, Livingstone MBE, Morrissey PA, Gibney MJ. Macronutrient intakes and food sources in Irish adults: findings of the North/South Ireland Food Consumption Survey. Public Health Nutr. 2001; 4(5A): 1051-60.

31 Livingstone MBE, Robson PJ, McCarthy S, Kiely M, Harrington K, Browne P, Galvin M, Wareham NJ, Rennie KL. Physical activity patterns in a nationally representative sample of adults in Ireland. Public Health Nutr. 2001; 4(5A): 1107-16.

32 Goris AHC, Westerterp-Plantenga MS, Westerterp KR. Undereating and underrecording of habitual food intake in obese men: selective underreporting of fat intake. Am.J. Clin. Nutr. 2000; 71: 130-4. 
33 Heitmann BL, Lissner L. Dietary underreporting by obese individuals - is it specific or non-specific. Br. Med. J. 1995; 311: 986-9.

34 Becker W, Foley S, Shelley E, Gibney MJ. Energy-underreporting in Swedish and Irish dietary surveys: implications for food based dietary guidelines. Br. J. Nutr. 1999; 81(Suppl. 2): S127-31.

35 Molarius A, Seidell JC, Tuomilehto J, Kuulasmaa K. Waist and hip circumferences and waist-hip ratio in 19 populations of the WHO MONICA Project. Int. J. Obes. 1999; 23: 11625.

36 Gregory J, Foster $\mathrm{K}$, Tyler $\mathrm{H}$, et al. The Dietary and Nutritional Survey of British Adults. London: HMSO, 1990.

37 Klesges RC, Eck LH, Isbell TR, Fulliton WT, Hanson CL. Smoking status: effects on dietary intake, physical activity and body fat of adult men. Am.J. Clin. Nutr. 1990; 51: 784-9.

38 James WPT, Ralph A. New understanding in obesity research. Proc. Nut. Soc. 1999; 58: 385-93. 